\title{
Pendampingan perencanaan, pengelolaan dan evaluasi pembelajaran berbasis proyek bagi guru matematika SMK Kota Mataram
}

\section{Baidowi', Dwi Novitasari2 ${ }^{*}$, Sri Subarinah ${ }^{3}$, Ratih Ayu Apsari ${ }^{4}$, Ni Made Intan Kertiyani ${ }^{5}$}

1,2,3,4,5 Pendidikan Matematika, FKIP, Universitas Mataram, Mataram

dwinovitasari@unram.ac.id

\begin{abstract}
This community service activity aims to provide assistance to SMK teachers in Mataram City in developing project-based learning to design, implement, and evaluate project-based mathematics learning. The specific target to be produced from this service activity is the optimal understanding of SMK teachers throughout the city of Mataram related to the planning, implementation, and evaluation of project-based mathematics learning. To achieve this target, mentoring was carried out for SMK teachers in Mataram City, each represented by 2 teachers in each partner school. Mentoring activities are carried out with a series of activities, namely (1) Seminars related to the general description of project-based learning and dissemination of research results that are still related to the need for project-based learning to be implemented in schools, (2) Workshop on project-based learning design, (3) Workshop on implementation project-based learning, (4) project-based learning evaluation workshops, (5) forum group discussion results from the implementation of activities in each school. The results of the service activities showed a positive response from the training participants and an increase in participants' understanding of project-based learning in mathematics learning.
\end{abstract}

Keywords: project-based learning; critical thinking; learning program

Abstrak

Kegiatan pengabdian kepada masyarakat ini bertujuan untuk memberikan pendampingan kepada guruguru SMK di Kota Mataram dalam mengembangkan pembelajaran matematika berbasis proyek mulai dari perancangan, pengimplementasian dan evaluasi pembelajaran matematika berbasis proyek. Target khusus yang ingin dihasilkan dari kegiatan pengabdian ini adalah optimalnya pemahaman guru-guru SMK se-kota Mataram terkait dengan perencanaan, implementasi dan evaluasi pembelajaran matematika berbasis proyek. Untuk mencapai target tersebut, dilakukan pendampingan guru-guru SMK di Kota Mataram yang masing-masing diwakili oleh 2 orang guru pada tiap-tiap sekolah mitra. Kegiatan pendampingan dilakukan dengan serangkaian kegiatan, yaitu (1) Seminar terkait dengan gambaran umum pembelajaran berbasis proyek dan desiminasi hasil penelitian yang masih berkaitan dengan perlunya pembelajaran berbasis proyek untuk diimplementasikan di sekolah, (2) Workshop perancangan pembelajaran berbasis proyek, (3) Workshop pengimpelementasian pembelajaran berbasis proyek, (4) Workshop evaluasi pembelajaran berbasis proyek, (5) FGD hasil implementasi kegiatan di sekolah masing-masing. Hasil kegiatan pengabdian menuinjukkan respon yang positif dari peserta pelatihan dan adanya peningkatan pemahaman peserta terhadap pembelajaran berbasis proyek dalam pembelajaran matematika.

Keywords: pembelajaran berbasis proyek; berpikir kritis; program pembelajaran 


\section{PENDAHULUAN}

Sekolah menengah kejuruan (SMK) merupakan salah satu satuan pendidikan formal yang menekankan pendidikan siswanya pada keterampilan kerja tertentu. Sesuai dengan bentuknya, SMK menyelenggarakan program-program pendidikan yang disesuaikan dengan jenis-jenis lapangan kerja (Peraturan Pemerintah Nomor 29 Tahun 1990). Nantinya, siswa-siswi yang lulus dari SMK diharapkan menjadi sumber daya manusia yang siap terjun ke dunia kerja (Undang-undang Nomor 20 Tahun 2003).

Kurikulum yang digunakan di SMK terus menerus diperbarui untuk menyesuaikan dengan kebutuhan kompetensi masa kini. Melalui Instruksi Presiden No. 9 tahun 2016, Kementerian Pendidikan dan Kebudayaan (Kemendikbud) diberikan arahan untuk menyesuaikan kurikulum SMK dengan kompetensi sesuai kebutuhan pengguna lulusan (link and match). Penyesuaian tersebut dilakukan antara lain dengan cara melakukan pembelajaran berbasis proyek kepada siswa. Pembelajaran berbasis proyek adalah pembelajaran yang berpusat pada siswa dimana siswa diminta untuk menyelesaikan suatu tugas di bawah bimbingan guru dan menjelaskan temuannya tanpa terlebih dahulu diberikan penjelasan teori seperti pada kelas tradisional (Serin, 2019). Dengan demikian, siswa dapat sedini mungkin melihat pengaplikasian pelajaran yang diperoleh di kelas ke dalam proyek yang dilakukan.

Kota Mataram memiliki delapan sekolah menengah kejuruan negeri. Sekolah-sekolah ini memberikan pendidikan pada bidang keahlian yang berbeda. Dari hasil observasi awal yang dilakukan pada guru-guru SMK di Kota Mataram diketahui mengalami beberapa kendala dalam proses membuat dan mengimplementasikan pembelajaran matematika yang berbasis proyek (project base learning). Selain itu, terdapat juga beberapa kendala yang dihadapi saat mengevaluasi kemampuan siswa yang mengikuti pembelajaran matematika berbasis proyek.

Untuk menelusuri permasalahan pada masyarakat sasaran, dilakukan pemberian kuesioner online kepada guru-guru matematika SMK se-kota Mataram. Dari data yang diperoleh, beberapa permasalahan mengenai pembelajaran matematika berbasis proyek dikelompokkan sebagai berikut:

1. Belum optimalnya pemahaman guru terkait dengan gambaran umum pembelajaran berbasis proyek.

Berdasarkan observasi awal yang dilakukan pada guru-guru matematika SMK di kota mataram diperoleh hasil bahwa guru-guru masih belum memahami secara penuh mengenai pembelajaran matematika berbasis proyek. Dari respon awal yang diberikan, 25\% guru menilai bahwa pada pembelajaran berbasis proyek, guru tidak perlu menyampaikan materi karena siswa akan mempelajari sendiri materi tersebut saat siswa melakukan proyek matematika yang diberikan.

2. Belum optimalnya pemahaman guru terkait dengan perancangan pembelajaran berbasis proyek. 
Melalui kuisioner yang diberikan kepada guru-guru SMK se-Kota Mataram diketahui bahwa seluruh responden pernah membuat pembelajaran matematika berbasis proyek. Dalam proses pembuatan pembelajaran matematika berbasis proyek, $50 \%$ responden menyampaikan beberapa tantangan yang dialami. Tantangan tersebut antara lain sulitnya mengaitkan setiap materi di jurusan dengan materi yang dipelajari di matematika. Dalam hal ini, terdapat kerumitan untuk mengaitkan materi matematika dengan proyek yang sedang dilakukan siswa pada mata pelajaran keahliannya. Selain itu, responden juga berpendapat bahwa tidak semua materi matematika bisa diajarkan menggunakan pembelajaran berbasis proyek.

3. Belum optimalnya pemahaman guru terkait dengan pengimpelementasian pembelajaran berbasis proyek.

Data yang berhasil dihimpun dari kuisioner menunjukan bahwa walaupun seluruh guru pernah merancang pembelajaran matematika berbasis proyek, namun hanya $75 \%$ guru yang pernah mengimplementasikan pembelajaran tersebut di kelas. Keseluruhan guru yang pernah menerapkan pembelajaran ini berpendapat bahwa model pembelajaran ini sangat menarik untuk diterapkan. Namun demikian, terdapat beberapa kendala yang ditemui saat mengimplementasikannya. Kendala tersebut antara lain kurangnya kemampuan peserta didik sehingga guru-guru harus mengeluarkan usaha tambahan untuk mensukseskan pembelajaran ini.

4. Belum optimalnya pemahaman guru terkait dengan evaluasi pembelajaran berbasis proyek.

Melalui kuesioner yang diberikan, diperoleh hasil bahwa semua guru yang pernah menerapkan pembelajaran matematika berbasis proyek juga pernah melakukan evaluasi siswa dalam pembelajaran ini. Dari respon yang diberikan, diketahui bahwa guru-guru mengevaluasi murid dalam bentuk pemberian soal-soal tertulis (paper based test). Dengan cara evaluasi tersebut, guru-guru mengakui kebanyakan siswa mengalami kesulitan memahami permasalahan yang diberikan. Siswa juga bertambah bingung jika permasalahan yang diberikan saat evaluasi berbeda dengan permasalahan yang diberikan saat pembelajaran.

Berdasarkan latar belakang tersebut maka tujuan dari kegiatan pengabdian ini adalah untuk mengoptimalkan pemahaman guru-guru matematika se-kota Mataram terkait perencanaan, pengimplementasian dan evaluasi pembelajaran matematika berbasis proyek

\section{METODE PELAKSANAAN}

Kegiatan pengabdian ini akan dilakukan sejak Februari-September 2021. Guruguru di sekolah mitra akan dibina dengan metode blok diskrit (Zepeda \& Mayers, 2006) yang sudah dimodifikasi oleh tim pengusul. Tahap awal kegiatan pendampingan, guru pertama kali akan diberikan gambaran umum mengenai pembelajaran berbasis proyek khususnya dalam pembelajaran matematika. 
Tahap kedua, guru diberikan materi dan pendampingan cara perancangan pembelajaran matematika berbasis proyek. Tahap ketiga, guru diberikan materi dan pendampingan cara mengimplementasikan pembelajaran matematika berbasis proyek di kelas yang sebelumnya telah dirancang. Tahap keempat, guru diberikan materi dan pendampingan terkait bagaimana mengevaluasi/memberikan penilaian terhadap pembelajaran matematika berbasis proyek, Tahap kelima, guru mengimplementasikan materi yang telah dipelajari pada tahap satu sampai empat yaitu mengimplementasikan kegiatan yang telah disusun pada sekolah masing-masing. Tahap keenam yaitu FGD hasil implementasi kegiatan di sekolah untuk mengetahui apakah ada kendala atau masalah yang dihadapi selama implementasi agar dapat didiskusikan bersama solusinya.. Flowmap tiap tahapan kegiatan pengabdian masyarakat kemitraan ini dapat dilihat pada gambar 1.

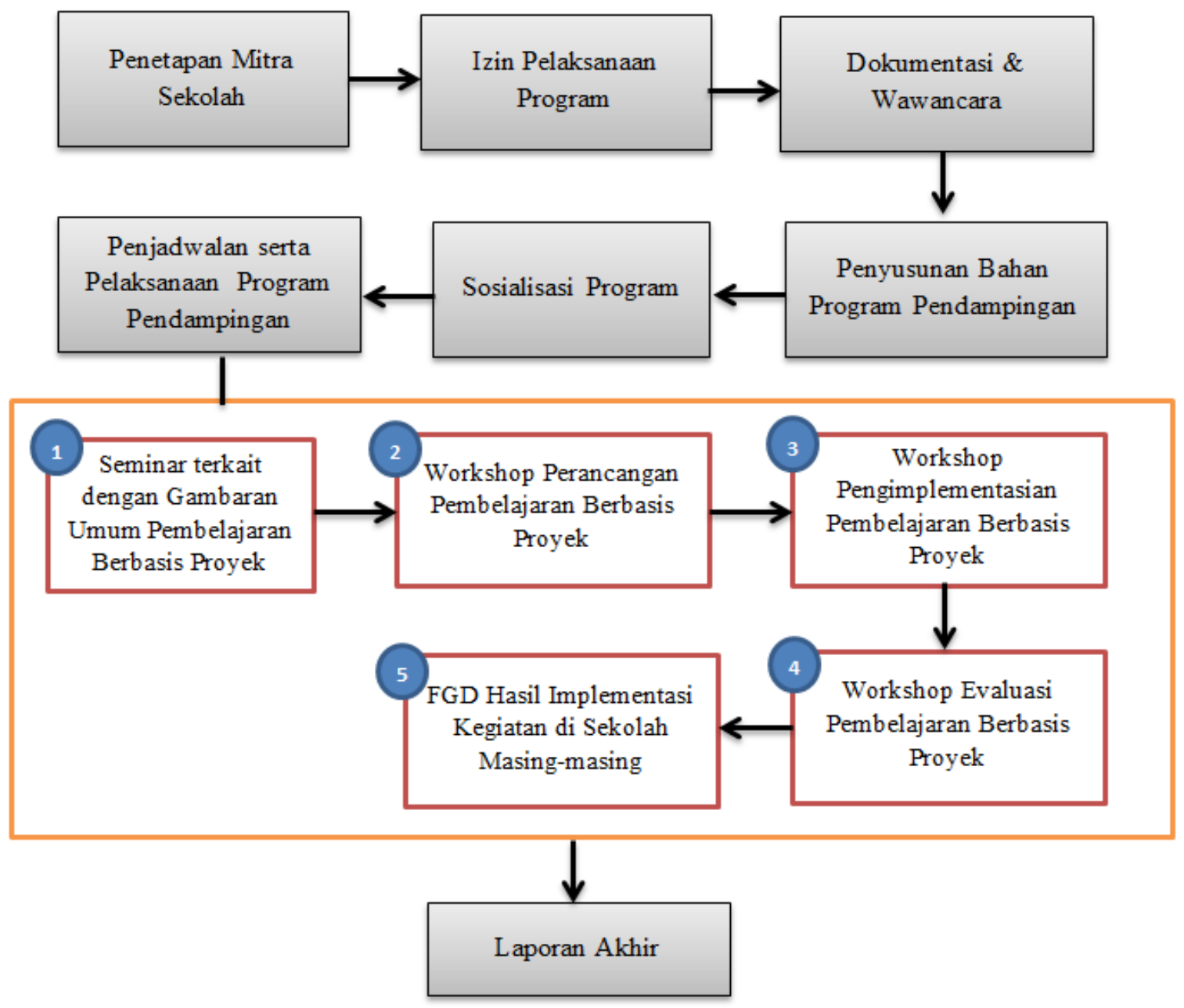

Gambar 1. Flowmap Tahapan Pelaksanaan Pengabdian Masyarakat Kemitraan

Tahapan-tahapan dalam flowmap pengabdian masyarakat dengan kemitraan ini akan dijelaskan dalam uraian berikut: 


\subsection{Penetapan Sekolah Mitra}

Penetapan sekolah mitra diawali dengan melakukan kerjasama dan diskusi dengan ketua MGMP Matematika SMK Kota Mataram sekaligus sebagai mitra dalam kegiatan pengabdian ini sekaligus sebagai penghubung dengan sekolah mitra. Hasil diskusi tersebut menetapkan bahwa sekolah mitra dalam kegiatan pengabdian ini adalah Sekolah Menengah Kejuruan (SMK) di Kota Mataram yang terdiri dari 8 sekolah yaitu SMKN 1, SMKN 2, SMKN 3, SMKN 4, SMKN 5, SMKN 6, SMKN 7 dan SMK PP Mataram. Pertimbangan lain dalam penentuan sekolah mitra yakni selain lokasi sekolah yang mudah dijangkau juga karena berdasarkan hasil observasi dan wawancara yang sebelumnya telah dilakukan terhadap perwakilan sekolah bahwa guru-guru mata pelajaran matematika mengalami kesulitan untuk merancang, mengimplementasikan dan mengevaluasi pembelajaran matematika yang berbasis proyek sehingga dibutuhkan adanya pendampingan terkait dengan hal tersebut.

\subsection{Izin Pelaksanaan Program}

Sebelum dilakukan kegiatan, maka pihak pengusul mengajukan kegiatan pendampingan bagi guru dalam merancang, mengimplementasikan dan mengevaluasi pembelajaran matematika berbasis proyek kepada Ketua MGMP Matematika SMK Kota Mataram dan sekolah mitra dengan membawa surat tugas dari ketua Lembaga Penelitian dan Pengabdian pada Masyarakat (LP2M) Universitas Mataram beserta proposal kegiatan pengabdian masyarakat kemitraan.

\subsection{Dokumentasi dan Wawancara}

Dokumentasi dimaksudkan untuk melihat atau menganalisis dokumen-dokumen terkait calon-calon guru-guru dari sekolah yang akan diberikan pendampingan serta untuk mengetahui seberapa jauh pemahaman guru mengenai pembelajaran matematika berbasis proyek, seperti dokumen pribadi (biodata diri), angket/kuesioner dan data pengembangan diri yang pernah diikuti guru terkait dengan pembelajaran matematika berbasis proyek. Sementara wawancara ditujukan untuk memeriksa kembali informasi atau keterangan yang diperoleh dari hasil dokumentasi dengan cara tanya jawab langsung tatap muka antara pengusul dengan informan (guru dan kepala sekolah mitra) yang diwawancarai (calon guru binaan).

\subsection{Penyusunan Bahan Program Pendampingan}

Pendampingan ini bermaksud untuk membantu guru dalam memahami pembelajaran berbasis proyek sehingga guru-guru SMK mampu merencanakan, mengimplementasikan dan mengevaluasi pembelajaran matematika berbasis proyek di kelas masing-masing. Oleh sebab itu, bahan program pendampingan akan dibuat dalam modul pelatihan sederhana bagi guru SMK yang menjelaskan: definisi pembelajaran berbasis proyek, hal-hal yang perlu diperhatikan dalam merancang pembelajaran berbasis proyek, syarat proyek yang baik untuk digunakan dalam pembelajaran, sintaks pembelajaran berbasis proyek serta evaluasi yang sesuai untuk pembelajaran berbasis proyek. 


\subsection{Sosialisasi Program}

Sosialisasi program dimaksudkan untuk memberikan arahan dan gambaran kegiatan yang akan dilakukan dan digunakan dengan mempertimbangkan berbagai aspek baik dari segi sarana dan prasarana serta calon guru binaan. Model pendampingan yang akan digunakan dalam pengabdian kepada masyarakat ini menggunakan model blok (Zepeda \& Mayers, 2006).

\subsection{Penjadwalan dan Pelaksanaan Program}

Penjadwalan dimaksudkan untuk menyesuaikan waktu dengan urutan kegiatan yang akan dilakukan agar seluruh kegiatan dapat terlaksana dengan baik dan sistematis. Apabila terdapat halangan di lapangan maka jadwal pada sekolah mitra dapat diubah dengan catatan tidak mengurangi porsi materi pendampingan yang diberikan. Kegiatan pendampingan ini akan dihadiri oleh 16 orang guru yang terdiri dari masing-masing 2 orang guru yang menjadi perwakilan dari 8 sekolah mitra (SMK di Kota Mataram), 2 orang alumni Program Studi Pendidikan Matematika serta tim pelaksana pengabdian yang terdiri dari 5 orang tim inti, 2 orang mahasiswa dan 1 tenaga administrasi. Kegiatan pendampingan yang akan dilakukan terdiri dari a) seminar terkait dengan gambaran umum pembelajaran berbasis proyek, b) workshop perancangan pembelajaran berbasis proyek, c) workshop pengimpelementasian pembelajaran berbasis proyek, d) workshop evaluasi pembelajaran berbasis proyek, dan e) FGD hasil implementasi kegiatan di sekolah masing-masing.

\section{HASIL DAN PEMBAHASAN}

\subsection{Proses Kegiatan Kegiatan}

Pengabdian kepada masyarakat ini dilakukan dengan kegiatan workshop pendampingan, perencanaan, pengelolaan dan evaluasi pembelajaran berbasis proyek bagi guru matematika SMK Kota Mataram yang dilakukan selama 2 hari. Kegiatan ini dilaksanakan di SMKN 3 Mataram. Kegiatan di mulai dengan melakukan survei lapangan untuk tahap penyusunan rencana kerja. Kegiatan survei ini dilakukan guna untuk mengidentifikasi permasalahan yang ada di sekolah yang dapat dicarikan solusinya dengan kegiatan masyarakat prodi Pendidikan Matematika FKIP Universitas Mataram. Selain itu, sebelum kegiatan pengabdian dilaksanakan, sebelumnya telah dilakukan kegiatan penelitian di salah satu SMK di Kota Mataram yaitu SMKN 3 Mataram untuk mengetahui hubungan atau korelasi antara kemampuan berpikir kritis siswa dengan kemampuan praktek kerja siswa sekolah menengah kejuruan (SMK) sebagai data awal. Hasil penelitian ini kemudian didesiminasikan pada hari pertama pelakanaan workshop. Berikut dijelaskan tiap tahapannya.

\subsubsection{Penetapan Sekolah Mitra}

Mitra dari kegiatan pengabdian ini adalah Sekolah Menengah Kejuruan (SMK) di Kota Mataram yang terdiri dari 8 sekolah yaitu SMKN 1, SMKN 2, SMKN 3, SMKN 4, SMKN 5, SMKN 6, SMKN 7 dan SMK PP Mataram yang masing-masing sekolah diwakili oleh masing-masing 2 orang guru matematika. 


\subsubsection{Izin Pelaksanaan Program}

Tim pengabdian melakukan koordinasi dengan Ketua MGMP Matematika SMK Kota Mataram untuk mengadakan kegiatan pendampingan bagi guru dalam merancang, mengimplementasikan dan mengevaluasi pembelajaran matematika berbasis proyek sekaligus mengirimkan draft rundown kegiatan yang akan dilaksanakan.

\subsubsection{Dokumentasi dan Wawancara}

Berdasarkan hasil wawancara, observasi dan pengisian angket awal terkait dengan gambaran awal pemahaman dan kemampuan guru terkait pembelajaran berbasis proyek dan pengimplementasian di kelas, diperoleh bahwa: (1) Pada umumnya guru telah mengetahui apa itu pembelajaran berbasis proyek hanya saja belum dipahami dengan baik. Sebanyak 25\% guru beranggapan bahwa pada pembelajaran berbasis proyek, guru tidak perlu menyampaikan materi dikarenakan siswa akan mempelajari sendiri materi tersebut saat siswa melakukan proyek matematika yang diberikan. (2) Guru kesulitan dalam menerapkannya di kelas dikarenakan guru kesulitan dalam menentukan atau mengaitkan materi matematika yang akan diajarkan dengan proyek yang harus dikerjakan siswa. Hal ini diperoleh dari angket respon guru dengan 50\% guru menilai demikian. (3) Dari respon yang diberikan, diketahui bahwa guru-guru mengevaluasi murid dalam bentuk pemberian soal-soal tertulis (paper based test). Dengan cara evaluasi tersebut, guru-guru mengakui kebanyakan siswa mengalami kesulitan memahami permasalahan yang diberikan. Siswa juga bertambah bingung jika permasalahan yang diberikan saat evaluasi berbeda dengan permasalahan yang diberikan saat pembelajaran.

\subsubsection{Penyusunan Bahan Program Pendampingan}

Hasil dokumentasi dan wawancara yang telah dilakukan dalam memperoleh data awal terkait pengetahuan dan kemampuan guru terkait pembelajaran berbasis proyek dijadikan sebagai salah satu referensi dan dasar dalam penyusunan bahan program pendampingan kegiatan workshop pendampingan, perencanaan, pengelolaan dan evaluasi pembelajaran berbasis proyek bagi guru matematika SMK Kota Mataram. Bahan program pendampingan disusun dalam bentuk modul yang terbagi menjadi beberapa bagian pembahasan yaitu: (1) Keterampilan berpikir kritis; (2) Keterampilan berpikir kritis bagi Siswa SMK; (3) Pembelajaran berbasis proyek di SMK; (4) Implementasi pembelajaran berbasis proyek; dan (5) Evaluasi pembelajaran berbasis proyek. Tiap bagian pda modul juga dilengkapi dengan contoh sehingga nantinya diharapkan guru lebih mudah dalam memahami serta mengimplementasikan hasil pelatihan ini di kelas pada sekolahnya masing-masing.

Bahan materi juga dilengkapi dengan slide presentasi atau PPt yang digunakan pada saat workshop. Berikut adalah beberapa contoh tampilan bahan program yang telah disusun (selengkapnya dapat dilihat pada Lampiran). 
Baidowi et al
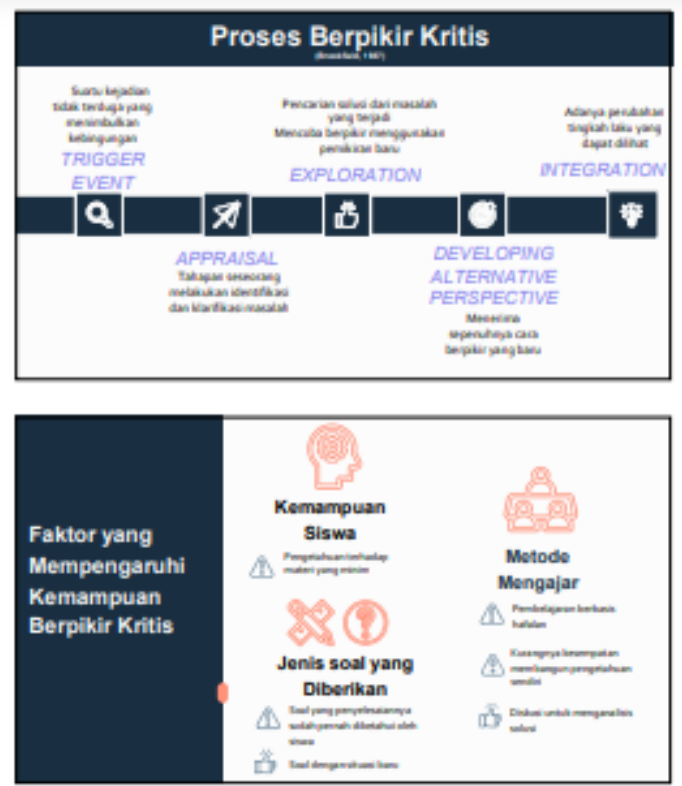

Pendampingan perencanaa, pengelolaan ...
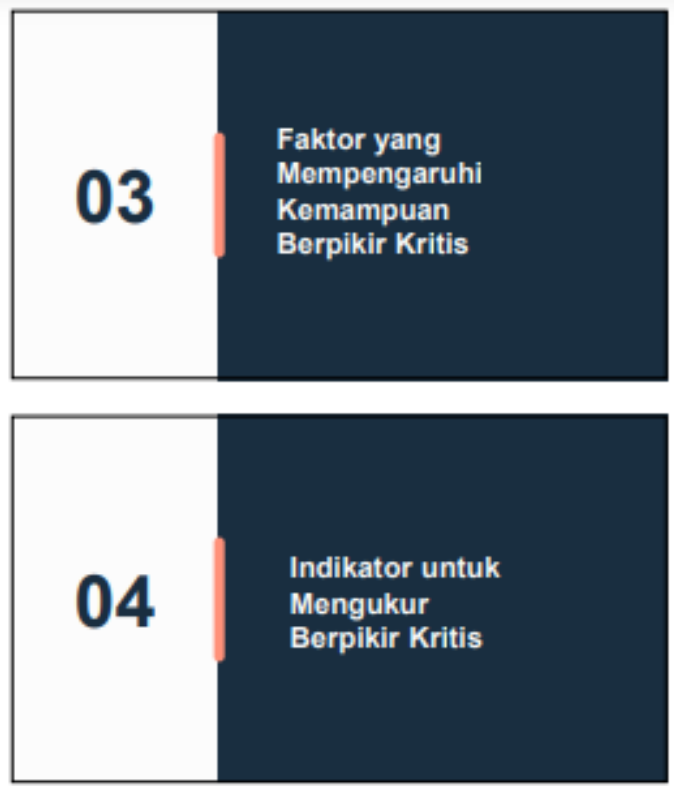

Gambar 2. Contoh tampilan modul bahan presentasi kegiatan pendampingan

\section{MATERI 3}

PEMBELAJARAN BERBASIS PROYEK DI SMK

Pembelajaran matematika di SMK selama ini mengalami kendala terkait dengan aktivitas siswa yang rendah sebagai akibat materi yang tidak terkait dengan kebutuhan siswa. Padahal kemampuan matematika yang baik dapat mendukung siswa dalam melakukan tugas-tugas praktek yang menjadi bidang keahliannya di SMK. Oleh sebab itu, perlu dilakukan perbaikan pembelajaran yang dapat mendukung perkembangan kemampuan matematika utamanya kemampuan berpikir kritis yang membantu siswa dalam membuat keputusan dan memecahkan masalah. Salah satu upaya pemerintah dalam perbaikan mutu pembelajaran matematika di SMK adalah dengan menerapkan pembelajaran berbasis proyek. Akan tetapi, dari hasil observasi awal di SMK di Kota Mataram diketahui bahwa guru-guru mata pelajaran matematika mengalami kesulitan untuk merancang, mengimplementasikan dan mengevaluasi pembelajaran matematika yang berbasis proyek. Oleh sebab itu, pengabdian ini berfokus pada pendampingan pembelajaran berbasis proyek kepada guru SMK agar dapat mengimplementasikannya di kelas.

Pembelajaran berbasis proyek adalah pembelajaran yang berpusat pada siswa dimana siswa diminta untuk menyelesaikan suatu tugas di bawah bimbingan guru dan menjelaskan temuannya tanpa terlebih dahulu diberikan penjelasan teori seperti pada kelas tradisional (Serin, 2019). Keunggulan dari pembelajaran berbasis proyek adalah mampu mengaktifkan siswa dalam belajar dan memberikan pengalaman belajar langsung yang menyebabkan siswa mampu mengembangkan keterampilan memecahkan masalah (Efstratia, 2014). Selain itu, pembelajaran berbasis proyek juga meningkatkan kemampuan komunikasi, negosiasi dan bekerja sama sehingga mampu mempersiapkan siswa dalam memasuki dunia kerja dan pergaulan di masyarakat (Indrawan et al., 2020). Model ini juga disebut mampu menjembatani kebutuhan dunia bisnis dengan kebutuhan belajar siswa (Cho \& Brown, 2013). Oleh karena itu, pembelajaran berbasis proyek dinilai ideal untuk diimplementasikan dalam pendidikan vokasi yang menekankan pada aspek keterampilan.

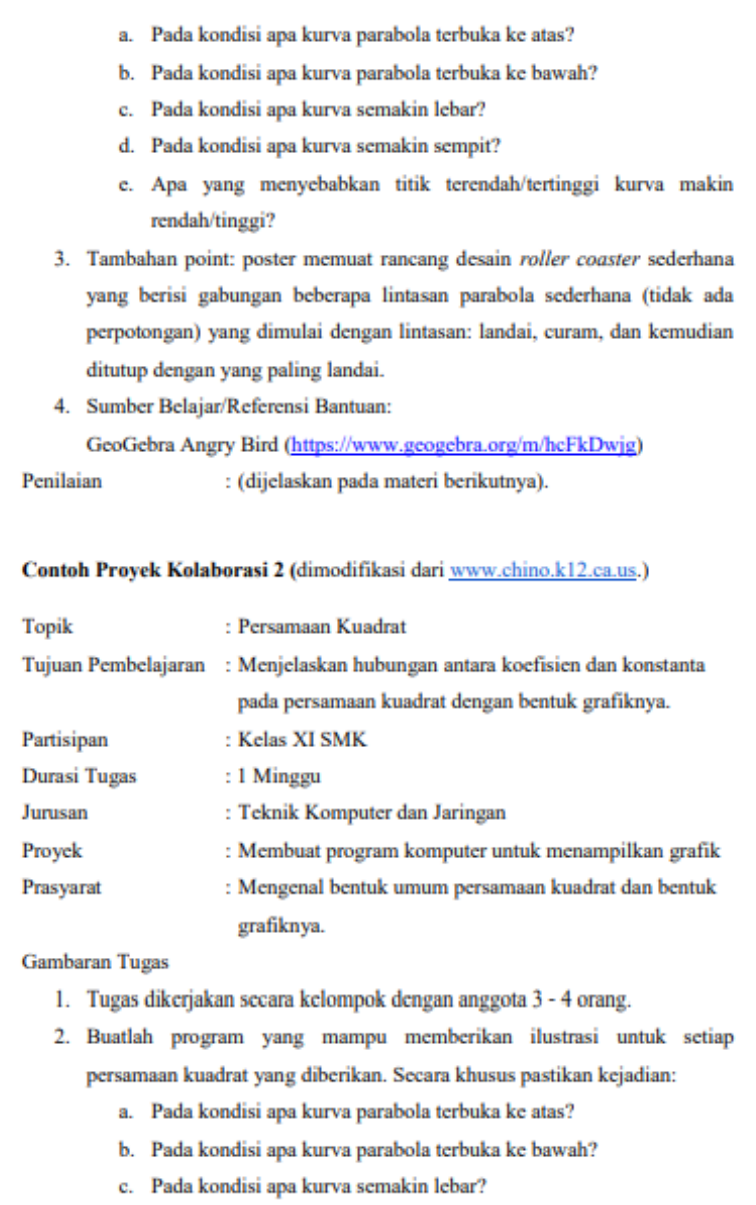

Gambar 3. Contoh tampilan modul berupa pembahasan disertai dengan contoh 


\subsubsection{Sosialisasi dan Pelaksanaan Program}

Kegiatan sosialiasi dilakukan dengan melakukan koordinasi dengan Ketua MGMP Matematika SMK Kota Mataram dan pihak sekolah mengenai bagaimana pentingnya pembelajaran berbasis proyek bagi siswa SMK khususnya SMK di kota Mataram. Hal ini disambut baik oleh ketua MGMP dan juga pihak sekolah.

Kegiatan pendampingan, perencanaan, pengelolaan dan evaluasi pembelajaran berbasis proyek bagi guru matematika SMK Kota Mataram dilakukan di SMAN 3 Mataram selama 2 hari. Hari pertama dilakukan workshop yang dimulai pukul 13.15 - 17.15 yang yang dihadiri oleh 17 orang perwakilan guru dari SMK se Kota Mataram. Kegiatan pendampingan terdiri dari (1) Diseminasi hasil penelitian "Korelasi Kemampuan Berpikir Kritis Matematika dan Kemampuan Praktek Kerja Siswa SMK".; (2) Pemaparan materi keterampilan berpikir kritis, keterampilan berpikir kritis bagi siswa SMK, perencanaan berbasis proyek di SMK, implementasi pembelajaran berbasis proyek di SMK dan evaluasi pembelajaran berbasis proyek di SMK. Pada kegiatan ini terlihat bahwa para peserta antusias dalam mengikuti kegiatan pelatihan. Peserta aktif dalam bertanya dan berdiskusi terkait dengan materi yang disampaikan oleh tiap pemateri; (3) Isoma; (4) Praktik pembuatan evaluasi pembelajaran berbasis proyek yang dilakukan oleh peserta pendampingan secara berkelompok. Pada kegiatan ini, tim pengabdian memberikan bimbingan dan bantuan kepada para peserta yang mengalami kesulitan atau kendala selama penyusunan; (5) Presentasi hasil evaluasi yang telah disusun oleh peserta dan diskusi; (6) Pengisian angket kepuasan dan penutupan kegiatan hari pertama.

Diseminasi hasil penelitian dimaksudkan sebagai gambaran bagi para guru SMK bahwa terdapat korelasi atau hubungan yang positif antara kemampuan berpikir kritis matematika dengan kemampuan praktek kerja siswa SMK. Oleh karena itu, penting bagi guru agar dapat mengembangkan kemampuan berpikir kritis matematika siswa. Salah satunya yaitu dengan menerapkan pembelajaran berbasis proyek.
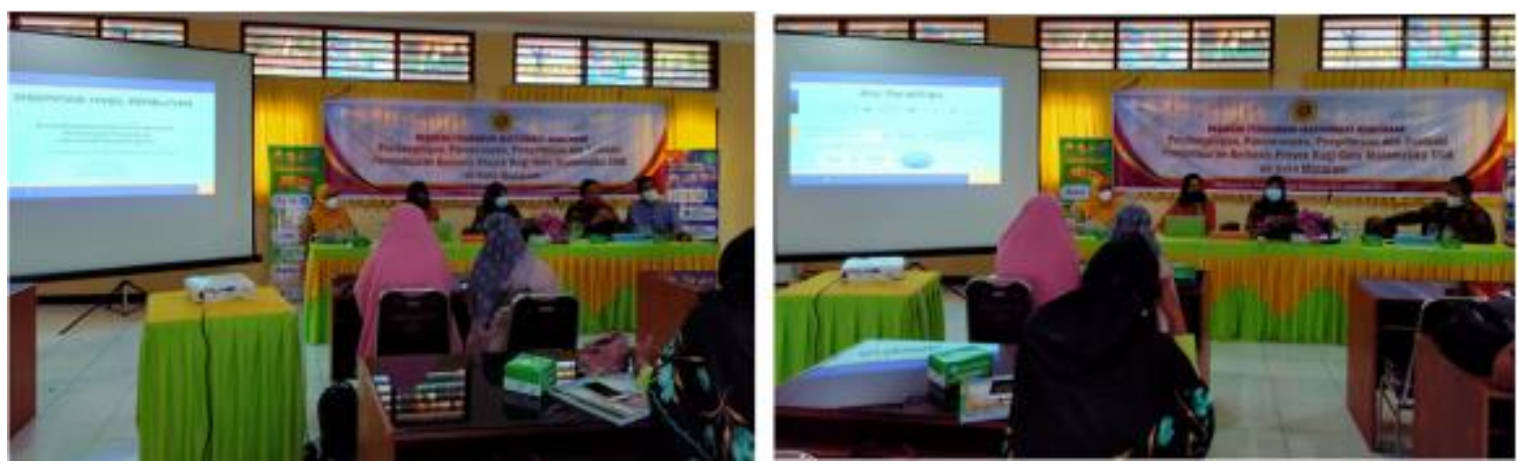

Gambar 4. Diseminasi hasil penelitian 
Setelah kegiatan desiminasi, dilanjutkan dengan penyampaian materi terkait project based learning (perencanaan berbasis proyek di SMK, implementasi pembelajaran berbasis proyek di SMK dan evaluasi pembelajaran berbasis proyek di SMK).
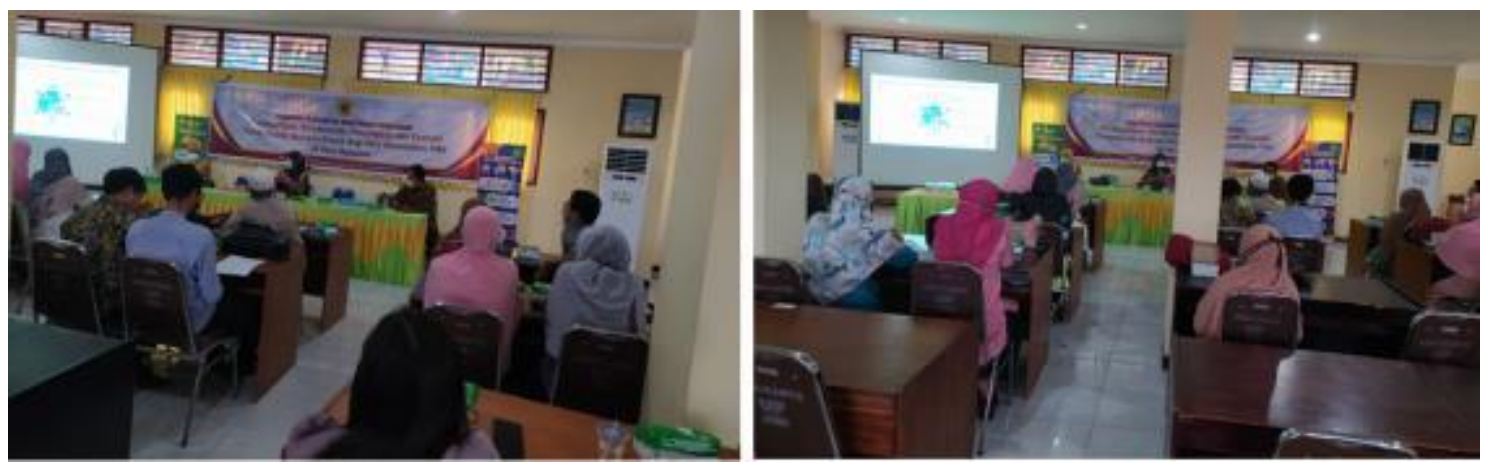

Gambar 5. Penyampaian materi program pendampingan

Peserta kegiatan sangat antusias dalam mendengarkan diseminasi dan penyampaian materi terkait project based learning. Hal ini dapat terlihat pada kegiatan diskusi dan tanya jawab, para peserta antusias untuk bertanya. Selain itu juga, sebagian dari mereka juga menceritakan terkait dengan permasalahan yang mereka alami saat di kelas dan mendiskusikan bersama cara untuk mengatasi permasalahan tersebut.
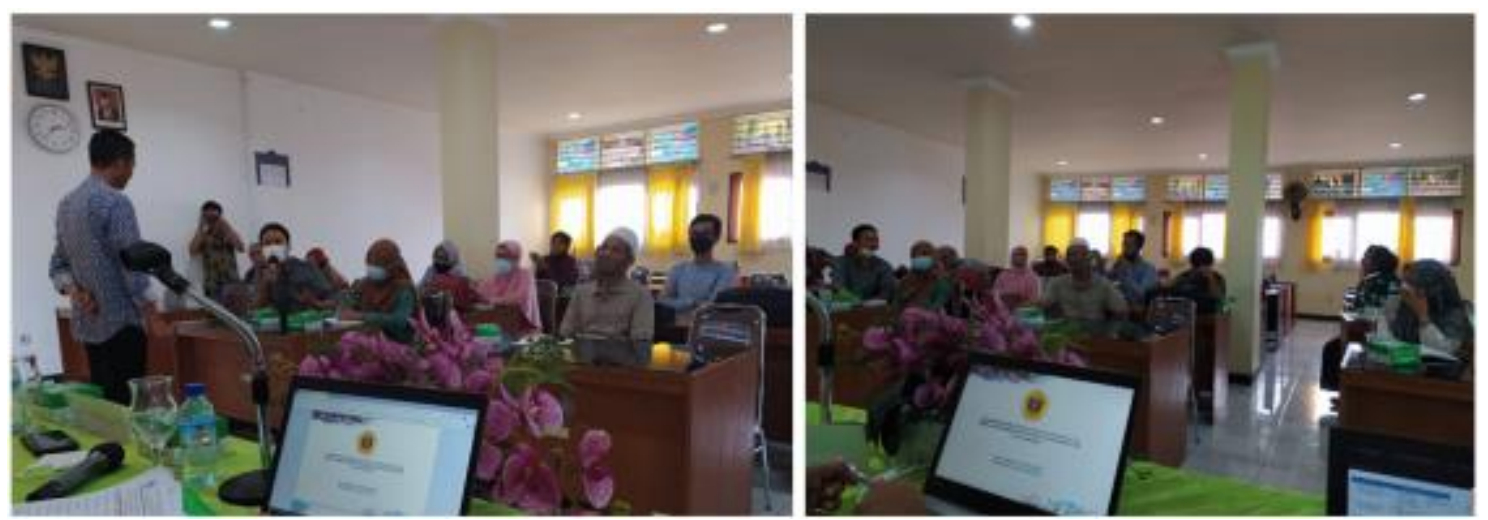

Gambar 6. Diskusi tanya jawab dengan peserta kegiatan

Kegiatan pendampingan hari kedua dilanjutkan dengan FGD dan Rencana Tindak Lanjut (RTL). Kegiatan ini bertujuan untuk berdiskusi terkait dengan hasil kegiatan workshop pada hari pertama yang sebelumnya telah diimplementasikan oleh peserta di sekolahnya masing-masing khususnya di kelasnya masing-masing. Kegiatan pendampingan hari kedua meliputi (1) Pembukaan; (2) Presentasi implementasi dari masing-masing sekolah (diwakili oleh beberapa peserta kegiatan); (3) FGD; (4) Isoma; (5) Rencana Tindak Lanjut (RTL); (6) Pengisian angket kepuasan oleh peserta kegiatan; dan (7) Penutup.

Dari kegiatan ini, terlihat bahwa cukup banyak peserta yang telah mengimplementasi hasil pelatihan yang telah dilakukan pada hari pertama meskipun juga terdapat 
beberapa kendala pada saat pengimplementasian diantaranya yaitu (1) Siswa awalnya merasa sedikit kesulitan karena biasanya mereka belum atau jarang menggunakan pembelajaran berbasis proyek dalam pembelajaran khususnya dalam membuat proyek yang terkait dengan matematika; (2) Guru sedikit mengalami kendala pada saat mengevaluasi hasil pembelajaran yang telah dilakukan khususnya dalam memberikan penilaian berdasarkan alat evaluasi yang telah disusun. Namun secara umum, guru telah mampu dalam mengimplementasikan pembelajaran berbasis proyek di sekolahnya masing-masing terlepas dari beberapa kendala yang dialaminya.

\subsection{Refleksi}

Pada tahap refleksi, semua peserta diberikan angket kepuasan pada hari pertama dan kedua terkait pelaksanaan kegiatan yang telah dilakukan. Dari angket yang telah diisi perseta diperoleh bahwa (1) 96,08\% peserta memberikan respon yang positif terkait kemampuan komunikasi dari narasumber (pemateri); (2) 60,78\% peserta memberikan respon positif terhadap implementasi dari kegiatan pendampingan yang dilakukan dimana kegiatan dapat diimplementasikan oleh guru dalam pembelajaran; (3) 91,18\% memberikan respon yang positif terkait dengan materi yang diberikan (Modul dan bahan presentasi); (4) $96,64 \%$ peserta memberikan respon positif terhadap kebermanfaatan kegiatan yang dilakukan. Seluruh peserta berharap bahwa kegiatan serupa dapat kembali dilakukan mengingat bahwa kegiatan pendampingan yang dihususkan bagi guru-guru matematika SMK seperti ini baru pertama kali dilakukan. Sebanyak 58,82\% peserta memberikan respon positif terhadap waktu pelaksanaan kegiatan. Sebagian besar peserta berharap bahwa kegiatan seperti ini dapat dilakukan dalam rentan waktu yang lebih banyak. Oleh karena itu, tim pengabdian memberikan ruang bagi para peserta kegiatan untuk dapat saling berdiskusi dan bertanya jika mengalami kesulitan atau hambatan selama merancang, mengimplementasikan ataupun melakukan evaluasi terhadap pembelajaran berbasis proyek yang mereka susun melalui grup whatsapp.

Selain itu, bagi peserta pelatihan yang memiliki kendala di dalam kelas terkait penbelajaran matematika juga dapat bertanya untuk dapat saling didiskusikan bagaimana solusi dari permasalahan yang dihadapi tersebut.
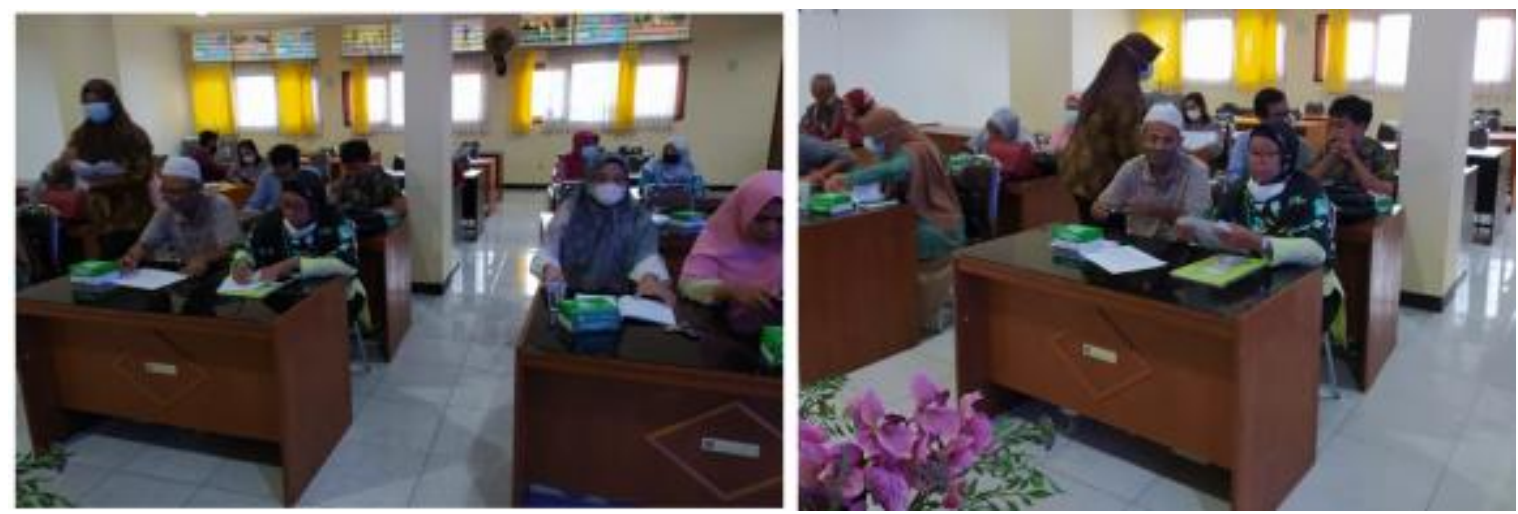

Gambar 7. Pengisian angket kepuasan oleh peserta kegiatan 
Kesimpulan dari refleksi menyatakan bahwa kegiatan pendampingan yang telah dilakukan memberikan respon positif dari para peserta pelatihan, namun masih ada yang perlu diperbaiki. Salah satunya yaitu contoh pengimplementasian pembelajaran berbasis proyek untuk beberapa jurusan yang di SMK khususnya dari contoh proyek yang dapat diberikan terkait dengan matematika.

Dengan adanya kegiatan pengabdian ini, para guru memperoleh pengetahuan dan kemampuan dalam merencanakan, merancang, mengimplementasikan pembelajaran berbasis proyek sebagai salah satu alternatif yang dapat digunakan dalam pembelajaran matematika untuk dapat memfasilitasi kemampuan berpikir kritis siswa. Sehingga nantinya diharapkan praktek kerja siswa juga dapat lebih baik. Selain faktor pendukung, terdapat pula faktor penghambat kegiatan pengabdian. Karena kegiatan pengabdian dilakukan dalam keadaan Pandemi, maka kegiatan pengabdian hanya dapat diikuti oleh perwakilan 2 orang masing-masing SMKN di Kota Mataram. Hal ini berdampak juga pada alokasi waktu yang terbatas. Namun, secara umum kegiatan pengabdian telah berjalan dengan sangat baik.

\section{SIMPULAN}

Berdasarkan kegiatan pendampingan, perencanaan, pengelolaan dan evaluasi pembelajaran berbasis proyek bagi guru matematika SMK Kota Mataram yang telah dilakukan dapat disimpulkan bahwa:

1. Peserta kegiatan memberikan respon yang positif terhadap kegiatan yang dilakukan.

2. Peserta kegiatan telah mampu mengimplementasikan pembelajaran berbasis proyek dalam pembelajaran matematika di sekolahnya masing-masing.

3. Pemahaman peserta kegiatan terhadap pembelajaran berbasis proyek khususnya dari segi perencanaan, pengelolaan dan evaluasi pembelajaran berbasis proyek meningkat dibandingkan dengan pembalajaran sebelum dilakukan kegiatan pelatihan.

\section{UCAPAN TERIMA KASIH}

Penulis mengucapkan terima kasih kepada pihak-pihak yang telah membantu dalam pelaksanaan kegiatan pengabdian masyarakat ini diantaranya yaitu: (1) LPPM Universitas Mataram yang telah mendanai pelaksanaan kegiatan pengabdian ini, (2) Program Studi pendidikan Matematika FKIP Universitas Mataram; (3) Ketua MGMP Matematika SMK Kota Mataram dan (4) Guru-guru SMK Negeri di Kota Mataram selaku peserta kegiatan.

\section{REKOMENDASI}

Pelaksanaan pelatihan ini telah berjalan dengan sangat baik. Partisipasi dan motivasi dari peserta pelatihan juga sangat baik. Namun demikian, masih terdapat beberapa 
kekurangan. Oleh karena itu tim pengabdian masyarakat Prodi Pendidikan Matematika FKIP Universitas Mtaram menyarankan hal-hal sebagai berikut. (a) Perlu adanya pelatihan yang kegiatan selanjutnya terkait dengan pembelajaran berbasis proyek bagi sekolah di SMK dan tidak hanya terbatas pada SMK di kota Mataram saja. (b) Kegiatan terkait pengimplementasian program dan evaluasi pembelajaran berbasis proyek dapat dilaksanakan lebih dari 2 kali mengingat peserta cukup mengalami kendala pada bagian ini.

\section{REFERENSI}

Beswick, K., Callingham, R., \& Muir, T. (2012). Teaching Mathematics in a Project-Based Learning Context: Initial Teacher Knowledge and Perceived Needs. Mathematics Education: Expanding Horizons. Proceedings of the 35th Annual Conference of the Mathematics Education Research Group of Australasia, 114-121.

Cho, Y., \& Brown, C. (2013). Project-based learning in education: Integrating business needs and student learning. European Journal of Training and Development, 37(8), 744-765. https://doi.org/10.1108/EJTD-01-2013-0006

Drake, K. N., \& Long, D. (2009). Rebecca's in the dark: A comparative study of problem-based learning and direct instruction/experiential learning in two 4th-grade classrooms. Journal of Elementary Science Education, 21(1), 1-16. https://doi.org/10.1007/bf03174712

Efstratia, D. (2014). Experiential Education through Project Based Learning. Procedia - Social and Behavioral Sciences, 152, 1256-1260. https://doi.org/10.1016/j.sbspro.2014.09.362

Flemming, D. . (2000). A Teacher's Guide to Project-Based Learning. In Charleston.

Indrawan, E., Jalinus, N., \& Syahril. (2020). Project-based learning in vocational technology education: Study of literature. International Journal of Scientific and Technology Research, $9(2), 2821-2825$.

Roessingh, H., \& Chambers, W. (2011). Project-Based Learning and Pedagogy in Teacher Preparation: Staking Out the Theoretical Mid-Ground. International Journal of Teaching and Learning in Higher Education, 23(1), 60-71.

Serin, H. (2019). Project Based Learning in Mathematics Context. International Journal of Social Sciences \& Educational Studies, 5(3). https://doi.org/10.23918/ijsses.v5i3p232

Zepeda, S. J., \& Mayers, R. S. (2006). An analysis of Research on Block Scheduling. Review of Educational Research, 76(1), 137-170. https://doi.org/10.3102/00346543076001137 